Lukasz Matusz

University of Silesia in Katowice, Poland

Anna Maria Rakowska

University of Silesia in Katowice, Poland
iD https://orcid.org/0000-0003-2810-5798

iD https://orcid.org/0000-0003-3237-1781

\title{
Self-reported Difficulties in Learning English as a Second Language for Third-age Students in Poland
}

\begin{abstract}
The problem of teaching English to third-age students is among the issues in ELT which have gained increasing attention and interest in recent years. The aim of this paper is to identify difficulties in learning English as a foreign language reported by students taking part in language courses at the Universities of the Third Age in Poland. The research is based on the questionnaire distributed among the group of 70 third-age students of English. The results show that the problems the learners report are cantered around their age- and health-related conditions, as well as their general attitudes concerning foreign language learning. It is hoped that the present study will constitute a minor contribution to the study of learning needs and expectations of senior students in Poland.
\end{abstract}

Keywords: ELT, language acquisition, third-age students, learning difficulties

\section{Introduction}

The problem of teaching English to third-age students is among the issues in ELT which have gained increasing attention and interest in recent years. Until quite recently, senior students in many respects were at a considerable disadvantage with regards to developing their language skills. Foreign language schools and other educational institutions did not use to offer a lot of classes for older students. In recent years, however, there has been an increasing number of foreign language courses organized for this group of learnars by different institutions, including the Universities of the Third Age in Poland. This ap- 
pears to come as a response to the growing demand from third-age students themselves.

Senior residents in Poland prove to be an increasingly self-conscious group of citizens, taking up on different activities and hobbies. Many of them have got families abroad, which urges them to be able to communicate with their children, their children's spouses, and their grandchildren. What is more, in contemporary Poland sufficient command of English is increasingly useful even in such mundane activities as everyday communication, reading names of products, services, and brands. Many third-age students seem to expect to keep up with the times also in this respect.

Although nowadays third-age students constitute an increasingly important group of English learners, for a long time their learning needs, learning styles, as well as ELT methodology concerning this group of students has been considerably underrepresented in the field of language learning studies. Researchers have tended to either focus more on other age groups of learners, or to discuss language teaching methodologies in general, without explicitly stating the needs and difficulties of older learners. There were also tendencies to describe senior students in a rather negative light.

Lenneberg (1967), for instance, claimed that third-age students were less able to learn a foreign language. Nowadays, other researchers have begun to question such claims and have noted that the abilities of third-age students to learn a foreign language are as good as those of younger learners.

According to Winitz (1981), it is crucial how teachers work with senior students and what methods and techniques are implemented in the process of teaching. According to Jaroszewska (2013, pp. 274-275), third-age students during foreign languages courses prefer note making, discussions that help them make the speaking skill more fluent, explanation of problems during each class, as well as individual work. Senior learners are also reported to appreciate learning through techniques showing the cultural and social aspect of language, as it helps them express their opinions and make use of their vast life experience in class. Moreover, the most interesting and effective courses for third-age students seem to be those ones which implement materials connected with students' everyday lives and which let them express their own opinions. Third-age students are more experienced and, thereby, often more able to clearly express their feelings than younger learners.

However, it is crucial to remember that third-age students may have different kind of motivation to learn a foreign language than children and working adults. Most seniors have already finished their professional lives; they frequently have no need to learn a foreign language for employment reasons. Their motivations for learning a foreign language often include travelling, being able to communicate with relatives or friends living abroad, proving themselves that they can learn no matter how old they are, etc. Third-age learners have 
got more time due to their retirement and they frequently intend to fulfill their time as beneficially as possible. It seems, therefore, significant to be able to assure them that language courses are not just for young learners who need to communicate fluently in the modern world.

The recent years have brought an increasing interest in the field of teaching senior persons. Niżegorodcew (2016) discusses third-age students' strengths and weaknesses in learning English as a foreign language. She describes how motivation and teacher's reflection on the course influences students' learning process. Niżegorodcew (2016, p. 89) claims that both affective and cognitive needs in the process of learning a foreign language are significant for senior students. They tend to use their memory and overcome the limitations connected with their age. Affective needs appear to be significantly important for this group of learners. Students commonly expect patience, understanding, and support from the teacher. What may make the teacher's work challenging is how to motivate senior students.

Mikołajczyk (2011) suggests that senior students may be afraid of new experiences as they do not know what to expect and do not experience sufficient emotional stability. This may lead them to being mistrustful toward the teacher and other members of the course. Since many seniors reveal a certain learning inferiority complex, a crucial aspect is to show them they are still able to learn a foreign language regardless of their age.

Grotek and Kiliańska-Przybyło (2012, p. 112) also describe the importance of emotions during language learning of seniors. Third-age students tend to pay more attention to affective factors than physical activities. They typically display high levels of emotional intelligence. Grotek and Kiliańska-Przybyło (2012) pay attention to the fact that most senior students are very sensitive people who need a lot of support during learning a language. Moreover, they like sharing their feelings with the teacher and other students. What differentiates senior students from younger learners is how they perceive failures in learning a foreign language. They are focused on their age and, thereby, they tend to take their failures quite personally and emotionally. Older learners also require more time during in-class speaking activities. Lack of fluency in speaking is strictly connected with searching for proper words or phrases and they may consider this a failure (Grotek \& Kiliańska-Przybyło, 2012, p. 122). Engaging in a foreign language classroom has been reported to have a beneficial effect in the well-being of senior learners. Grzanka-Tykwińska and Kędziora-Kornatowska (2010, p. 30) maintain that being active makes third-age students feel healthier and improve their mental capacity. Nevertheless, although they have possibilities to learn a language, fear of failure sometimes is the reason they are not sure whether it is a good idea to start such activity at their particular age.

For the reasons described above, another important issue in teaching thirdage students is the awareness of their strengths and weaknesses in the process 
of learning English. Niżegorodcew (2016, p. 90) believes that these two aspects depend not only on students' age but also on the aims of foreign language learning and the strategies they use. The clue is that students who learn a foreign language for pleasure and to affiliate with other people can be more satisfied with the learning than students who are focused on achievement and success. It can be observed, for instance, that third-age students are not afraid of tests as a factor in their professional development. They are more frequently afraid of them as a possible demonstration of their personal failure. They commonly fear that they are not as effective in the learning process as they would like to be. Therefore, it becomes important for the teacher to observe what strengths senior students possess and focus students' attention on these features in order to improve their self-esteem.

The teacher must take into consideration all the facts influencing third-age students and choose proper methods to implement and appropriate roles to fulfill during the course. According to Harmer (2000, p. 57), it is crucial for the teacher to make a proper decision. Working with senior students requires the teacher to be particularly supportive, as third-age students' self-confidence is frequently on a lower level compared to younger learners. Another important factor which the teacher must take into consideration is older learners' participation in discussions. Senior students do not like being assessed and instructed in a strict way, but they predominantly enjoy being part of modern society. Older persons who enroll for third-age language courses do that of their own will. They predominantly look forward to the aspects of their learning which are connected to socializing with other people and maintaining their social activity.

Nonetheless, language courses for senior students come with certain considerable difficulties. It has been reported that such learners have problems with their self-esteem and that the objective problems connected with their age may interfere with the process of learning. The main purpose of this article is to identify the focal areas of self-reported difficulties in learning English as a second language which such students experience. The research is based on the questionnaire survey distributed among students of group courses of English in the context of Polish learners. Our sincere thanks must go here to those course leaders in different academic institutions who have kindly agreed to allow us to carry out this study with their groups. In particular, we are greatly indebted to Monika Grotek (The University of the Third Age at the University of Silesia in Katowice), who has greatly facilitated our research. It is hoped that the information gathered through the questionnaire analysis will prove to be helpful as a minor step towards a better understanding of the learning needs and difficulties for this particular group of students. 


\section{Research Aims and Methodology}

The aim of the questionnaire survey was to identify the most common self-reported difficulties in learning English as a second language for third-age students in the context of the surveyed group of Polish learners and to provide additional relevant information about the participants of the study. The research tool was a questionnaire distributed between the months of January and March 2017 among the students of English courses organised by different third-age universities in the region of Silesia in Poland. The questionnaire was distributed in two complementary formats: paper form and electronic version. Both versions were identical in the questions asked and their phrasing. The questionnaire was distributed in Polish in order to facilitate feedback from students of different levels of English. It consists of the total of 11 questions, including eight closed multiple-choice questions and three open questions. The original paper version of the questionnaire is presented in Appendix 1. What follows below is a short explanation of the questions in the study.

In Question 1 of the questionnaire the subjects are asked to identify their sex: male (Mężczyzna) or female (Kobieta). The aim of Question 2 is to identify the age of the respondents as belonging to one of the four groups (50-55, 56-60, 61-65, 65 and above). Question 3 refers to how long the participants have been learning English as a second language. The four available options include: shorter than one year, 1-3 years, 4-6 years, 7-9 years, 10 years and more. In Question 4 the subjects are asked to identify the reasons for learning English. They are instructed to choose one or more than one option ranging from the purposes of work, travelling, self-satisfaction, social goals, and others.

Question 5 serves as the main research question of the questionnaire. The participants are asked to mark one of the options referring to the extent to which they agree with 11 language-learning related sentences. The sentences in their English translation are as follows:

1. English is a difficult language to learn.

2. In certain age it is impossible to learn a foreign language well.

3. Younger learners are able to learn to communicate faster than older ones.

4. Older persons can understand language problems better than younger ones.

5. I lack patience in learning English as a foreign language.

6. I need a lot of support from the teacher in learning a foreign language.

7. Older persons are usually more conscientious about their learning than younger ones. 
8. It is easier for older persons to understand different language issues due to their life experience.

9. It is easier for me to learn if I have grammar explained to me step-bystep.

10. Regular language revisions are important for me.

For each of the above questions the participant is required to mark one of the following options:

- I fully agree

- I generally agree

- I don't have an opinion

- I generally disagree

- I strongly disagree

Question 6 is a supplementary question for Question 5. It is aimed at finding out if the participants have experienced different age-related difficulties or illnesses in connection with their learning. If the answer is in the affirmative, the respondents are requested to specify what types of age related-problems they typically encounter in the process of learning English as a foreign language. Questions 7 and 8 are related as the participants are asked to decide which language skills are the most important for them (Question 7) and which ones are the most problematic in the learning process (Question 8). Both questions have the same range of available answer options:

- Speaking/communication skills

- Listening skills

- Reading skills

- Vocabulary practice

- Grammar practice

- Others (Please specify:

Finally, Questions 9-11 serve as three optional open questions in the questionnaire. In Question 9 the participants are asked to identify other, previously unspecified, difficulties they encounter in the process of learning English as a foreign language. Question 10 is aimed at finding out if the respondents feel discomfort during classes and-if yes-in what situations it typically occurs. Finally, in Question 11 the subjects are requested to provide 3-4 features which in their opinion characterise a good teacher. The three non-obligatory questions at the end of the questionnaire are meant to provide extra information relevant for the discussion of language learningrelated difficulties. The results of the survey and their analysis are presented below. 


\section{Results of the Survey}

In total, between the months of January and March 2017 a sample of 70 respondents took part in the questionnaire. All of the participants were students of stationary English courses organized by third-age universities in the region of Silesia in Poland. There were sixty-four female (91\%) and six male $(9 \%)$ respondents. The participants were all in the broad category of third-age learners: at the age of 50 years old or above: fourteen subjects $(20 \%)$ between 50 and 55, nine subjects (13\%) between 56 and 60, twenty-two subjects (31\%) between 61 and 65 , and twenty-five subjects (36\%) above the age of 66 . The reasons for learning English among those persons proved to be quite varied. Only six participants (9\%) cited the purposes of work, nine subjects (13\%) reported social reasons. The majority of the respondents, though, provided the purposes of travelling (45 subjects, 64\%) and self-satisfaction (57 subjects, $81 \%$ ). Other reasons for learning a foreign language were cited by five senior students. Their answers oscillated around the reasons of socialising (e.g., I like the lessons with our teacher), family matters (I have a family in England), and practical applications of learning (Being able to read shop signs, product names, being able to use new technologies, etc.). Since the participants were allowed to choose more than one answer, the percentages in question 4 do not add up to 100 . What these findings might suggest is that many third-age students in the Polish context treat their learning as a social and self-motivating undertaking, most of them being past their professional life, they no longer need to learn for the purposes of work. Instead, in their courses they commonly seek elements of socialising, meeting new people, cultivating friendships, and staying active to the old age. These tendencies seem to be even more prominent among the older participants of the study: the six respondents who reported learning English for the purposes of work were all between the ages of 50 and 60 . On the other hand, $91 \%$ of persons between 61 and 66 and $80 \%$ of the participants over the age of 66 reported their own satisfaction as a reason to take up the courses, as opposed to $71 \%$ and $78 \%$ in the age groups of $50-55$ and $56-60$ respectively. The motivation connected with students' self-satisfaction may be connected with increasing self-consciousness of the older generation in Poland. As Grzanka-Tykwińska and Kędziora-Kornatowska (2010, p. 30) imply, senior students may be aware that learning a foreign language can serve as a factor in slowing down the processes of mental ageing and improving their mental capacities.

The results of Question 5, the main research question in the study, are presented in Table 1. 
Table 1.

Question 5: analysis

\begin{tabular}{|l|c|c|c|c|c|c|}
\hline \multicolumn{1}{|c|}{ Survey Questions } & $\begin{array}{c}\text { I fully } \\
\text { agree. }\end{array}$ & $\begin{array}{c}\text { I generally } \\
\text { agree. }\end{array}$ & $\begin{array}{c}\text { I don't } \\
\text { have an } \\
\text { opinion. }\end{array}$ & $\begin{array}{l}\text { I generally } \\
\text { disagree. }\end{array}$ & $\begin{array}{l}\text { I strongly } \\
\text { disagree. }\end{array}$ & Total: \\
\hline $\begin{array}{l}\text { English is a difficult language } \\
\text { to learn. }\end{array}$ & $9(13 \%)$ & $27(39 \%)$ & $14(20 \%)$ & $15(21 \%)$ & $5(7 \%)$ & 70 \\
\hline $\begin{array}{l}\text { In certain age it is impossible } \\
\text { to learn a foreign language } \\
\text { well. }\end{array}$ & $8(12 \%)$ & $24(34 \%)$ & $9(13 \%)$ & $17(24 \%)$ & $12(17 \%)$ & 70 \\
\hline $\begin{array}{l}\text { Younger learners are able to } \\
\text { learn to communicate faster } \\
\text { than older ones. }\end{array}$ & $67(57 \%)$ & $17(24 \%)$ & $2(3 \%)$ & $3(4 \%)$ & $1(1 \%)$ & 70 \\
\hline $\begin{array}{l}\text { Older persons can understand } \\
\text { language problems better than } \\
\text { younger ones. }\end{array}$ & $4(6 \%)$ & $20(29 \%)$ & $27(39 \%)$ & $14(20 \%)$ & $5(6 \%)$ & 70 \\
\hline $\begin{array}{l}\text { I lack patience in learning } \\
\text { English as a foreign language. }\end{array}$ & $8(11 \%)$ & $17(24 \%)$ & $13(19 \%)$ & $20(29 \%)$ & $12(17 \%)$ & 70 \\
\hline $\begin{array}{l}\text { I need a lot of support from } \\
\text { the teacher in learning a for- } \\
\text { eign language. }\end{array}$ & $20(29 \%)$ & $33(47 \%)$ & $6(9 \%)$ & $9(13 \%)$ & $2(2 \%)$ & 70 \\
\hline $\begin{array}{l}\text { Older persons are usually } \\
\text { more conscientious about their } \\
\text { learning than younger ones. }\end{array}$ & $16(23 \%)$ & $25(36 \%)$ & $20(29 \%)$ & $6(9 \%)$ & $3(3 \%)$ & 70 \\
\hline $\begin{array}{l}\text { It is easier for older persons to } \\
\text { understand different language } \\
\text { issues due to their life experi- } \\
\text { ence. }\end{array}$ & $7(10 \%)$ & $15(21 \%)$ & $16(23 \%)$ & $23(33 \%)$ & $9(13 \%)$ & 70 \\
\hline $\begin{array}{l}\text { It is easier for me to learn if } \\
\text { I have grammar explained to } \\
\text { me step-by-step. }\end{array}$ & $32(46 \%)$ & $30(43 \%)$ & $5(7 \%)$ & $3(4 \%)$ & $0(0 \%)$ & 70 \\
\hline $\begin{array}{l}\text { Regular language revisions } \\
\text { are important for me. }\end{array}$ & $48(69 \%)$ & $19(27 \%)$ & $2(3 \%)$ & $1(1 \%)$ & $0(0 \%)$ & 70 \\
\hline
\end{tabular}

What follows from the results is that a lot of difficulties reported by thirdage students in the surveyed group originated from their self-consciousness and their attitudes and anxieties concerning foreign language learning. Senior learners generally agreed that English was a difficult language to learn. The combined $52 \%$ of the respondents either fully or generally identified with this statement. Third-age students, however, were not predominantly pessimistic concerning their ability to learn a foreign language. As many as $46 \%$ of the participants agreed that at a certain age it is impossible to learn a foreign language well, as opposed to $41 \%$ of subjects who disagree with Statement 2. Only $13 \%$ of the respondents said that they had no opinion on this matter. On the other hand, senior students were aware of the language-learning limitations connected with their age. The majority of the subjects $(67 \%)$ fully 
agreed that younger learners were able to learn to communicate better than older ones. Twenty-four percent of senior students responded "I generally agree" to this statement. Thus, the combined percentage of the respondents who agreed with Statement 3 reaches $91 \%$. This stands in vivid contrast to the combined $8 \%$ of the respondents who had no opinion on the matter or disagreed with the statement. The respondents also did not tend to consider their age as an asset for their ability to understand language problems better than younger learners. Thirty-five percent of the subjects agreed with Statement 4 with 26\% disagreeing and 39\% undecided. Reportedly, the life experience they possess was not felt to be an advantage either, as demonstrated by $43 \%$ of the subjects disagreeing with Statement 8 . What follows is that third-age students tended to be aware of their limitations and problems in the process of learning a foreign language. They revealed certain level of insecurity concerning their learning abilities and tended to think of themselves as subordinate to their younger colleagues when it comes to their foreign language acquisition faculties. Perhaps due to these limitations, the subjects also felt that they needed a lot of support from the teacher in the process of learning, as demonstrated by the combined $76 \%$ of the respondents agreeing with Statement 6. Also, the majority of older students appear to find it easier to learn if they have grammar explained to them step-by-step. The combined $89 \%$ either fully or generally agreed with this claim, as opposed to the combined $11 \%$ who either disagreed or voiced no opinion on the matter (Statement 9). What is also important is that regular revisions of the learning material are important for the vast majority of the participants (96\%). This suggests that third-age students are also aware of their learning difficulties connected with memory, memorising and retrieving words, expressions and grammatical constructions. On the positive side, however, many of the respondents were of the opinion that older persons were usually more conscientious than younger learners (the combined 59\% with only 13\% disagreeing as a response to Statement 7). Also, a significant percentage of senior students (46\%) did not think of themselves as lacking patience in learning a foreign language, as opposed to the $34 \%$ of the participants who responded in the affirmative to Statement 5 .

As a response to Question 6 in the questionnaire, 38 participants (54\%) reported experiencing difficulties with learning a foreign language which were related to their age-specific illnesses or conditions, with 32 subjects $(46 \%)$ answering in the negative. Among those who responded in the affirmative, the types of age-related difficulties were significantly consistent: $30(79 \%)$ respondents reported different problems related to memory and concentration (e.g., short memory, problems with memorising language material, concentration difficulties). The categories of hearing difficulties, general health problems and other conditions were each reported by three students $(8 \%)$. This pertains 
to the fact that the respondents are aware of the problems of their age, especially the fact that their memory does not work as efficiently as is the case of younger students.

The analysis of answers in Questions 7 and 8 provides information about the language skills which are important and problematic for the respondents. In response to Question 7 as many as 66 participants (94\%) reported speaking and communication as the most important language skills. A similarly high percentage $(70 \%, 49$ students) was associated with listening skills. Reading skills were reported as important by 33 students (47\%), while vocabulary and grammar practice were given respectively 17\% and 14\% (12 and 10 students).

The language skills which are most important for third-age students appear to be largely congruent with those which are reported to be particularly problematic. Speaking and communication appears to be a problem for 37 participants (53\%). An even higher percentage of the respondents $(67 \%$, 47 persons) reported listening as a particularly problematic language skill. The following problematic language ability appears to be grammar practice (18 students, 26\%) and writing (15 respondents, 21\%). The least problematic language skills among those cited by the respondents were vocabulary practice (13 students, 19\%) and reading skills (eight respondents, $11 \%$ ). What follows is that the language skills which are most important for the third-age students taking part in the survey are largely consistent with those which prove to be most problematic for them. Interestingly, listening skills were more frequently reported as problematic than speaking and communication skills, which may be due to certain age-related conditions, including hearing deficiencies, in some of the participants.

Another set of data which is important to analyse here is the participants' answers to Question 9. The question is aimed at identifying other, previously unspecified, areas of difficulties reported by third-age students taking part in the questionnaire. Thirty-nine students (54\%) reported experiencing such difficulties in the process of learning English, as opposed to 31 participants $(46 \%)$ who responded in the negative. Those who answered in the affirmative often focused on different problems related to memory (e.g., problems with memorising, when I forget important words), problems with pronunciation (e.g., I am not sure if I pronounce something correctly), problems with speaking and communication (e.g., I have problems to communicate in English, I am stressed when I speak in class), and difficulties with listening skills (e.g., I have hearing problems, I find it difficult to understand dialogues from the $C D$ ). The summary of the problems reported is provided in Table 2. Since in Questions 7-9 the participants were allowed to choose more than one answer, the percentage values in Table 2 do not add up to $100 \%$. 
Table 2.

Question 9: analysis

\begin{tabular}{|l|c|c|}
\hline $\begin{array}{c}\text { Other learning-related problems reported } \\
\text { by third-age students } \\
\text { (Question 11) }\end{array}$ & $\begin{array}{c}\text { Number of } \\
\text { respondents }\end{array}$ & $\begin{array}{c}\text { Percentage of } \\
\text { respondents } \\
(\%)\end{array}$ \\
\hline Problems with memory & 9 & 23 \\
\hline Problems with pronunciation & 8 & 21 \\
\hline Problems with speaking & 7 & 18 \\
\hline Problems with listening & 6 & 15 \\
\hline Problems with concentration & 5 & 13 \\
\hline Problems with grammatical tenses & 5 & 13 \\
\hline Problems with sentence forming & 2 & 5 \\
\hline Lack of time for studying & 2 & 5 \\
\hline Short duration of classes & 2 & 5 \\
\hline Others & 3 & 8 \\
\hline Total & 39 & 100 \\
\hline
\end{tabular}

The analysis of the results in response to Question 9 appears to corroborate the earlier findings of the study. In particular, the language learning difficulties for third-age students surveyed in the questionnaire tend to be connected with their memory/concentration problems, as well as with difficulties with speaking/ pronunciation and listening. This may reflect the objective limitations connected with the age-related conditions these students experience.

As a response to Question 10, wherein the respondents were asked if they felt discomfort during classes, 26 participants (37\%) responded in the affirmative. The analysis of their feedback points to the aforementioned difficulties connected with students' problems concerning speaking/communication, difficulties with memory and memorisation and problems connected with pronunciation. The detailed results are provided in Table 3.

What the analysis of the answers to Question 10 shows is that the main sources of discomfort among the researched group of students were connected with the problem areas which the respondents reported in other questions, especially in connection to speaking/conversation and listening tasks.

Finally, the analysis of self-reported difficulties in learning English as a foreign language among the surveyed group of third-age students is complemented by Question 11, wherein the students were asked to identify 3-4 features of a good teacher. Among the leading characteristics the participants provided were: patience (forty-four students, 61\%), ability to pass on knowledge (sixteen students, 22\%), leniency/empathy (fifteen students, $21 \%$ ), communicativeness (twelve students, 17\%), kindness (eight students, 11\%), professionalism (nine students, 12.5\%), positive attitude (six students, 8\%), knowledge (six students, $8 \%$ ), 
systematicity (five students, 7\%), openness (five students, 7\%), ability to motivate students (five students, $7 \%$ ), humour (five students, $7 \%$ ), good pronunciation (five students, 7\%). Other characteristics of a good teacher provided by students included the expectations that the teacher be competent (three students), involved in lessons (three students), well-organised (three students), well-mannered (three students) able to match the pace of classes with students' capabilities (three students), consequent (two students), creative (two students), calm (two students), flexible (one student), able to use different sources of learning materials (one student), able to create good atmosphere for learning (one student), experienced (one student), demanding (one student), willing to speak exclusively in English (one student), competent in audio-video equipment (one student), able to explain grammar well (one student), focused on building students' self-confidence (one student), respectful of students' subjectivity (one student).

Table 3.

Question 10: analysis

\begin{tabular}{|l|c|c|}
\hline \multicolumn{1}{|c|}{$\begin{array}{c}\text { Other sources of in-class discomfort experienced } \\
\text { by students (Question 12) }\end{array}$} & $\begin{array}{c}\text { Number of } \\
\text { respondents }\end{array}$ & $\begin{array}{c}\text { Percentage of } \\
\text { respondents } \\
\text { (\%) }\end{array}$ \\
\hline Speaking/conversation & 8 & 31 \\
\hline Listening & 5 & 19 \\
\hline Memory problems & 3 & 12 \\
\hline Vocabulary practice & 2 & 8 \\
\hline Fast pace of classes & 2 & 8 \\
\hline Grammar exercise & 1 & 4 \\
\hline Pronunciation & 1 & 4 \\
\hline My being unprepared & 1 & 4 \\
\hline When other students speak better English & 1 & 4 \\
\hline Different level of English in group & 1 & 4 \\
\hline I'm not sure if I am able to manage to learn English. & 1 & 4 \\
\hline Total & $\mathbf{2 6}$ & $\mathbf{1 0 0}$ \\
\hline
\end{tabular}

What follows, therefore, is that third-age students taking part in the survey predominantly expected patience and leniency in their teacher, followed by the ability to pass on knowledge and communicativeness. This reveals the picture of many of these students being dependable in their learning, looking for a lot of support and not willing the teacher to be excessively demanding or strict. This, again, may be the result of third-age students in then research group revealing a comparatively lower level of self-esteem and self-confidence when it comes to learning English as a foreign language. 


\section{Conclusions}

The analysis of the survey conducted among a group of Polish third-age students of English shows that the self-reported difficulties of the research group fall into two main categories. Firstly, there are objective, often health- and agerelated problems that such students experience. Most frequently, the subjects tended to complain about the efficiency of their memory, frequent forgetting of words and constructions, problems with memorising and retrieving language material which they had already learnt. As a result, they considered regular revisions of learning material to be of utmost importance. Senior students were convinced that they were less able to focus on the lesson than younger students and that they generally required more time to acquire the learning material. Another frequent condition reported by this group of learners is the hearing problems. As a result, senior students found activities such as classroom audio listening stressful and difficult. The third-age students also found it problematic to speak in full sentences and use complex language constructions in front of the group. They were unsure of their ability to pronounce words and expressions properly. For many of them, the inability to pick up the appropriate accent was a significant difficulty.

The other category of difficulties that the participants reported was connected with third-age students' attitudes towards teaching and learning a foreign language. Senior students in the questionnaire were generally aware of their limitations and drawbacks, including those which resulted from their advanced age and health conditions. They were convinced that younger students were able to learn a foreign language faster and better than persons of their age. Also, they felt that they needed a lot of support from the teacher. It was, reportedly, easier for them to learn if they had grammar explained step-by-step and in an accessible way. Many senior students required constant reassuring, positive class atmosphere, as they were not confident that they may be able to learn a foreign language at an appropriate level. Thus, a constant challenge for the teacher working with such a group was to motivate them, show them the constant progress they were making and creating comfortable and learningconducive environment.

The data emerging from the study of self-reported difficulties among third-age students appears to confirm earlier observations of Niżegorodcew (2016), Grzanka-Tykwińska and Kędziora-Kornatowska (2010), and Grotek and Kiliańska-Przybyło (2012). The learning needs of third-age students are often centred on creating and maintaining positive language learning environment for them. Consequently, in working with such groups, among the most important qualities of a language teacher are those soft competence skills which are aimed at supporting and helping. The social skill which was most welcome by 
the students in the survey was patience. This might be connected with those students' knowledge and consciousness of their limitations and inadequacies. Senior students often learn foreign languages for the purposes of socialising, travelling, contacting their family abroad and for their own satisfaction. The most important language skills which the respondents reported in the study included speaking/communication and listening skills. Interestingly, these language skills were also reported as being among the most problematic ones. The research shows significant congruity in answers given by the participants of the study. Third-age students in the Polish context appear to treat their learning as a social and self-motivating endeavour, as they enjoy the elements of socialising, which Grotek and Kiliańska-Przybyło (2012) discuss. Many of those students focus on the positive group-building attitudes and communication-enhancing emotions. From the teacher they expect patience, ability to transfer knowledge, leniency, empathy and good communication skills. At the same time, they are not usually looking for demanding and strict language learning instructors. This is also congruent with Niżegorodcew (2016), who suggests that older students often learn a foreign language for pleasure and in order to socialize with their peers. Having - on the whole - finished their professional lives, they are not pressed by the demands of their employers or the prospects of promotion. Instead, in their courses they search for elements of spending time in a group, meeting new people, the possibilities for cultivating friendships and family ties. At the same time, the growing social consciousness concerning health and well-being of senior citizens in Poland allows for the possibility that this group of students are themselves aware of what Grzanka-Tykwińska and KędzioraKornatowska (2010) suggest, namely that regular language courses constitute a factor in slowing down the processes of mental ageing and improving thirdage students' mental capacities and social well-being.

On the positive side, the image of third-age students which emerges from the study is of individuals who are positive towards their learning, as they have willingly opted to take the courses which they participate in. They have positive reasons for learning English, that is, socialising, mental exercise, communicating with their families etc. Third-age students appear to be respectful towards their teachers, searching for and emphasizing their positive qualities. They are students who are self-conscious and aware of their limitations and drawbacks. As a result, they tend to be realistic towards their learning prospects and learning process.

On the other hand, the research shows a picture of students who are largely dependent on the teacher, persons who are not sure about their ability to learn a foreign language and individuals who expect a significant degree of support and frequent motivation from the teacher. They are persons who reveal a high level of anxiety towards their learning. They feel comfortable with considerable amount of guidance from the teacher and expect a lot of support and reassur- 
ance. What appears to be seen in other studies is to what extent this kind of attitude is the result of the objective difficulties of such students experience in the process of learning English and to what extent this is the effect of their earlier learning and schooling experience. Those students in the course of their lives have received formal education, and the attitudes they have acquired in the course of their learning may have influenced their current attitudes.

What seems to be rather clear and significant is the fact that there is a need for more research into the learning needs of senior learners. The interest in this age group and their methodology, although by all means worthwhile and important, currently appears to be insufficient and not representative of the number of third-age students undertaking courses in different institutions in Poland. With the growing life expectancy, the growing self-consciousness of thirdage students and the increasing number of courses for them, there is a need for more vivid interest in the learning needs, difficulties, and expectations held by older learners. It remains to be seen, therefore, what direction further enquiries into the learning needs and difficulties of senior learners in Poland will take.

\section{References}

Brown, D. H. (2000). Principles of language learning and teaching. New York: Longman.

Grotek, M., \& Kiliańska-Przybyło, G. (2012). Rola czynników afektywnych w procesie nauki języka obcego przez osoby w wieku senioralnym. In Teraźniejszość-Człowiek-Edukacja, (3/59). Wrocław: Wydawnictwo Naukowe Dolnośląskiej Szkoły Wyższej.

Grzanka-Tykwińska, A., \& Kędziora-Kornatowska, K. (2010). Znaczenie wybranych form aktywności w życiu osób w podeszłym wieku. Gerontologia Polska, 18/1.

http://www.edukacja.senior.pl/130,0,Nauka-jezykow-obcych-a-wiek,12699.html

Jaroszewska, A. (2013a). Nauczanie języków obcych seniorów w Polsce. Kraków: Wydawnictwo Impuls.

Jaroszewska, A. (2013b). Gdzie, jak i dlaczego polscy seniorzy uczą się języków obcych? Języki obce w szkole, 4, Uniwersytet Warszawski.

Lenneberg, E. H. (1967). Biological foundations of language. New York: Wiley.

Mikołajczyk, K. (2011). Jak uczą się dorośli, czyli co powinien wiedzieć trener o specyfice kształcenia uczestników szkolenia. E-mentor 2/39. Retrieved from: http://www.e-mentor. edu.pl/artykul/index/numer/39/id/831

Niżegorodcew, A. (2016). Studying English in senior years: A psycholinguistic perspective. In D. Gałajda, P. Zakrajewski, \& M. Pawlak (Eds.), Researching second language learning and teaching from a psycholinguistic perspective: Studies in honour of Danuta GabryśBarker. Basel: Springer International Publishing.

Winitz, H. (1981). The comprehension approach to foreign language instruction. Rowley, MA: Newbury House Publishers. 
Badanie trudności w nauce języka angielskiego u osób w wieku 50+

Szanowni Państwo,

Bardzo dziękujemy za zgodę na wypełnienie poniższej ankiety.

Ankieta dotyczy trudności w nauce języka angielskiego wśród osób po 50. roku życia. Składa się ona z 11 pytań. Jej wypełnienie zajmie Państwu ok. 5-10 minut. Badania przeprowadzane są w ramach projektu badawczego prowadzonego w Instytucie Języka Angielskiego Uniwersytetu Śląskiego. Ankieta jest całkowicie anonimowa. Zebrane dane zostaną wykorzystane wyłącznie do celów naukowych.

1. Proszę zakreślić swoją płeć.

- Mężczyzna

- Kobieta

2. Ile ma Pan(i) lat?

- $50-55$

- $56-60$

- 61-65

- Powyżej 65

3. Od jak dawna uczy się Pan(i) języka angielskiego?

- Krócej niż 1 rok

- Od 1-3 lat

- Od 4-6 lat

- Od 7-9 lat

- 10 lat i więcej

4. W jakim celu uczy się Pan(i) języka angielskiego? (Można zaznaczyć więcej niż jedną odpowiedź)

- Dla celów związanych z pracą

- Dla celów związanych z podróżowaniem

- Dla własnej satysfakcji

- Dla celów towarzyskich

- Inne (jakie?)

5. Proszę zaznaczyć, w jakim stopniu zgadza się Pan(i) z następującymi zdaniami. (Proszę zaznaczyć znak X w odpowiednim polu). 


\begin{tabular}{|c|c|c|c|c|c|}
\hline Pytania ankietowe & $\begin{array}{l}\text { Zgadzam się } \\
\text { w zupełności }\end{array}$ & $\begin{array}{c}\text { Generalnie się } \\
\text { zgadzam }\end{array}$ & $\begin{array}{l}\text { Nie mam } \\
\text { zdania }\end{array}$ & $\begin{array}{c}\text { Generalnie się } \\
\text { nie zgadzam }\end{array}$ & $\begin{array}{l}\text { Nie } \\
\text { zgadzam się } \\
\text { w zupełności }\end{array}$ \\
\hline $\begin{array}{l}\text { 1. Język angielski jest języ- } \\
\text { kiem trudnym w nauce. }\end{array}$ & & & & & \\
\hline $\begin{array}{l}\text { 2. W pewnym wieku nie } \\
\text { można się już języka an- } \\
\text { gielskiego dobrze nauczyć. }\end{array}$ & & & & & \\
\hline $\begin{array}{l}\text { 3. Osoby młodsze potrafią } \\
\text { nauczyć się komunikować } \\
\text { w języku obcym szybciej } \\
\text { niż osoby starsze. }\end{array}$ & & & & & \\
\hline $\begin{array}{l}\text { 4. Osoby starsze potrafią } \\
\text { zrozumieć problemy języ- } \\
\text { kowe lepiej niż osoby } \\
\text { młodsze. }\end{array}$ & & & & & \\
\hline $\begin{array}{l}\text { 5. Brakuje mi cierpliwości } \\
\text { w nauce języka angiel- } \\
\text { skiego. }\end{array}$ & & & & & \\
\hline $\begin{array}{l}\text { 6. Potrzebuję sporo wsparcia } \\
\text { ze strony lektora podczas } \\
\text { nauki. }\end{array}$ & & & & & \\
\hline $\begin{array}{l}\text { 7. Osoby starsze zwykle } \\
\text { bardziej przykładają się do } \\
\text { nauki niż osoby młodsze. }\end{array}$ & & & & & \\
\hline $\begin{array}{l}\text { 8. Osobom dojrzałym łatwiej } \\
\text { jest zrozumieć różne } \\
\text { kwestie językowe z powodu } \\
\text { większego doświadczenia } \\
\text { życiowego. }\end{array}$ & & & & & \\
\hline $\begin{array}{l}\text { 9. Łatwiej jest mi się uczyć } \\
\text { kiedy mam wytłumaczoną } \\
\text { gramatykę krok po kroku. }\end{array}$ & & & & & \\
\hline $\begin{array}{l}\text { 10. Ważne są dla mnie regu- } \\
\text { larne powtórki językowe. }\end{array}$ & & & & & \\
\hline
\end{tabular}

6. Czy odczuwa Pan(i) trudności w nauce języka angielskiego związane z dolegliwościami swojego wieku?

- Nie

- Tak (jakiego rodzaju?)

7. Jakie umiejętności językowe są dla Pana/Pani ważne? (Można zaznaczyć więcej niż jedną odpowiedź).

- Umiejętność komunikacji/porozumiewania się

- Umiejętność rozumienia ze słuchu

- Umiejętność czytania

- Umiejętność pisania

- Ćwiczenie słownictwa 
- Ćwiczenie gramatyki

- Inne (jakie?):

8. Nauka jakich umiejętności językowych sprawia Panu/Pani najwięcej problemów? (Można zaznaczyć więcej niż jedną odpowiedź).

- Umiejętność komunikacji/porozumiewania się

- Umiejętność rozumienia ze słuchu

- Umiejętność czytania

- Umiejętność pisania

- Ćwiczenie słownictwa

$€$ Ćwiczenie gramatyki

$€$ Inne (jakie?):

9. Jakie inne trudności odczuwa Pan(i) podczas nauki języka angielskiego?

10. Czy odczuwa Pan(i) dyskomfort podezas nauki? Jeśli tak, to $w$ jakich sytuacjach?

11. Jakie cechy według Pana/Pani cechują dobrego nauczyciela? (3-4 cechy) 